\title{
LITERASI KEUANGAN BAGI GENERASI MILLENNIAL DI ERA PANDEMI COVID-19
}

\author{
Dina Sartika \\ dina.sartika@ unpad.ac.id \\ Arie Widyastuti \\ arie.widyastuti@unpad.ac.id \\ Mery Citra Sondari \\ mery.sondari@unpad.ac.id
}

\section{UNIVERSITAS PADJADJARAN}

\begin{abstract}
ABSTRAK
Penelitian tentang perilaku keuangan menunjukkan bahwa Generasi Millennial lebih banyak menghabiskan uang untuk konsumsi daripada menabung dan investasi. Gaya hidup konsumtif tersebut disebabkan tuntutan gaya hidup dan rendahnya literasi keuangan di kalangan millennial. Lebih lanjut, maraknya perusahaan investasi yang menjanjikan kemudahan dan keuntungan yang besar dalam waktu singkat juga perlu diantisipasi guna mencegah kejahatan atau penipuan yang marak terjadi. Kegiatan Pengabdian Kepada Masyarakat ini bertujuan untuk memberikan sosialisasi mengenai pentingnya pengelolaan keuangan pribadi. Secara spesifik, kegiatan ini bertujuan untuk meningkatkan literasi keuangan di kalangan millennial agar mereka dapat mengelola keuangan dengan baik. Disamping itu, kegiatan ini juga memberikan informasi mengenai berbagai instrumen keuangan yang dapat dimanfaatkan oleh generasi millennial dengan mempertimbangkan keuntungan dan risiko dengan bijak. Sasaran kegiatan ini meliputi generasi millennial di Indonesia. Kegiatan dilakukan secara virtual melalui Live Instagram dan telah disaksikan oleh 580 orang.
\end{abstract}

Kata kunci: Generasi Millennial, Investasi, Literasi Keuangan, Manajemen Keuangan.

\section{PENDAHULUAN}

Angkatan kerja di Indonesia saat ini didominasi oleh generasi millennial dengan porsi rata-rata 50 persen dari seluruh generasi usia di segala sektor. Dibandingkan dengan generasi-generasi sebelumnya, generasi milennial lebih mementingkan keseimbangan antara kehidupan personal dengan karir mereka dan terkenal lebih konsumtif. Penelitian terdahulu menunjukkan bahwa generasi millennial lebih banyak menghabiskan uang untuk konsumsi daripada menabung dan investasi (Azizah, 2020). Perilaku konsumtif atau membeli yang berlebihan bukanlah lagi mencerminkan kegiatan atau usaha manusia untuk menggunakan uang secara ekonomis, namun hal tersebut dijadikan sebagai cara untuk menghadirkan diri atau mendapatkan pengakuan diri dengan cara yang tidak tepat. Hal ini mengakibatkan para generasi millennial yang notebene saat ini memasuki dunia kerja banyak sekali yang terjebak dalam perilaku dan gaya hidup konsumtif. 
Hal ini terjadi karena masih rendahnya literasi keuangan di kalangan millennial (Prayustika, Suryadi, Arsawan, \& Widiantara, 2020; Yolanda \& Tasman, 2020).

Literasi keuangan (financial literacy) adalah pengetahuan seseorang dalam mengelola keuangan. Pengelolaan tersebut mencakup berbagai aspek antara lain simpanan, pinjaman, konsumsi, dan investasi (Chen \& Volpe, 1998). Dalam pengelolaan keuangan individu (personal finance) terdapat tiga keputusan inti, yaitu keputusan mengenai penentuan sumber dana, penggunaan dana, serta perencanaan pensiun (Hussain \& Sajjad, 2016).

Penelitian terdahulu menemukan bahwa literasi keuangan berdampak positif terhadap kesejahteraan individu. Hal ini karena pengetahuan keuangan yang dimiliki seseorang akan menentukan perilaku dalam mengambil keputusan keuangan (Ningtyas, 2019;Rosdiana, 2020). Lebih lanjut, perencanaan keuangan bermanfaat bagi seseorang dalam mengendalikan diri dan mempersiapkan kondisi finansial terbaik bagi masa depannya. Selain itu, dengan perencanaan keuangan yang baik seseorang dapat memiliki jaminan keuangan yang aman (secure) dan membantu meraih citacita financial secara efisien dan efektif. Sebaliknya, tingkat literasi keuangan yang rendah dapat menyebabkan masyarakat mengalami penurunan kesejahteraan akibat ketidakefektifan dalam pengambilan keputusan keuangannya (Hussain \& Sajjad, 2016).

Saat ini banyak sekali perusahaanperusahan yang menawarkan investasi dengan iming-iming keuntungan besar dalam waktu singkat. Di samping itu, maraknya perusahaan finansial berbasis teknologi (fintech) yang menyasar kaum millennial memberikan banyak alternatif bagi mereka dalam meangalokasikan pendapatannya. Pertumbuhan finansial teknologi dan perkembangan produkproduk keuangan tersebut bukan hanya menyediakan berbagai alternatif investasi dan pendanaan bagi konsumen, tetapi juga tantangan untuk semakin memahami manfaat serta biaya yang dikeluarkan oleh berbagai inovasi tersebut. Secara ideal setiap orang diharapkan berpikir rasional dalam memilih produk keuangan, agar bukan hanya terhindar dari transaksi-transaksi yang bersifat financially destructive, tetapi juga mampu secara realistis menganalisis berbagai tawaran investasi yang ada sehingga dapat dengan tepat membuat keputusan keuangan yang dapat mengoptimalkan hasil dan meminimalisasi risiko.

Berdasarkan latar belakang di atas, maka pokok permasalahan yang akan menjadi perhatian dalam kegiatan Pengabdian Kepada Masyarakat (PKM) ini adalah untuk melakukan sosialisasi dan edukasi mengenai literasi keuangan (financial literacy) kepada generasi millennial. Hal ini dilakukan dengan harapan agar generasi milennial dapat memiliki tingkat pengetahuan keuangan yang lebih baik dan literasi keuangan yang memadai. Dengan demikian, kesejahteraan mereka dapat meningkat dan cita-cita finansial mereka dapat tercapai.

\section{METODE KEGIATAN}

Kegiatan ini dilakukan dengan mengidentifikasi permasalahan yang dihadapi oleh generasi millennial terkait pengelolaan keuangan. Berdasarkan identifikasi masalah tersebut maka disusun program dan materi terkait penyelesaian masalah tersebut. Selanjutnya, tim menentukan metode yang tepat untuk diimplementasikan mengingat situasi pandemi Covid-19 ini yang tidak memungkinkan melakukan kegiatan sosialisasi dan edukasi secara langsung. Setelah ditentukan metode yang tepat, maka pelaksanaan kegiatan dapat dilakukan.

\subsection{Khalayak Sasaran}

Target peserta dari kegiatan ini adalah generasi millennial Indonesia. Karena kegiatan ini dilakukan secara virtual dan ditayangkan di akun media sosial Instagram tim, masyarakat luas tentu saja dapat 
menyaksikan. Dengan demikian, lebih banyak masyarakat yang memperoleh benefit dari tayangan kegiatan tersebut.

\subsection{Metode yang Digunakan}

Pemberian edukasi mengenai literasi keuangan dan pengetahuan mengenai pengelolaan keuangan dilakukan secara virtual melalui media sosial Instagram. Meskipun dilakukan secara virtual, diskusi tetap dilakukan secara interaktif dalam format talk show dimana terjadi dialog interaktif antara nara sumber dan peserta. Tahapan kegiatan Pengabdian Kepada Masyarakat adalah sebagai berikut:

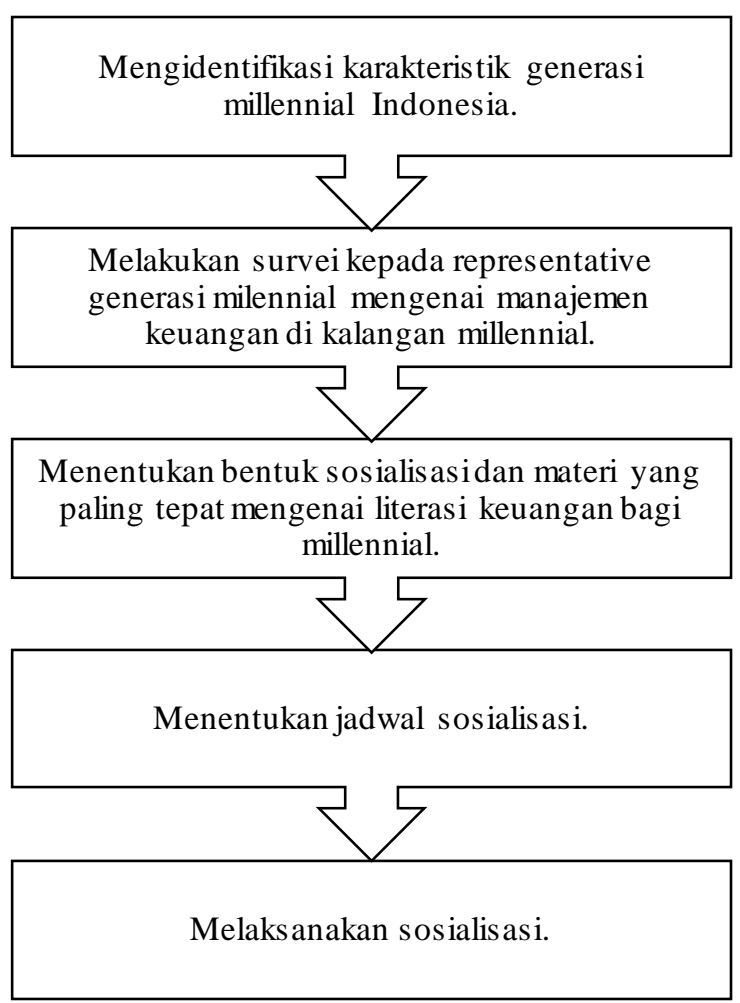

Gambar 1. Tahapan Kegiatan.

\section{HASIL DAN LUARAN}

Pelaksanaan PKM dimulai dengan brainstorming serta mengidentifikasi karakteristik demografis generasi millennial Indonesia. Tahapan selanjutnya adalah mengkaji lebih jauh tentang permasalahan ekonomi yang dihadapi oleh generasi milennial, terlebih lagi dengan adanya kondisi pandemi Covid-19. Identifikasi permasalahan ekonomi dan perilaku manajemen keuangan di kalangan millennial dilakukan secara interaktif melalui Instagram story @ dina_sartika pada tanggal 5 Oktober 2020.

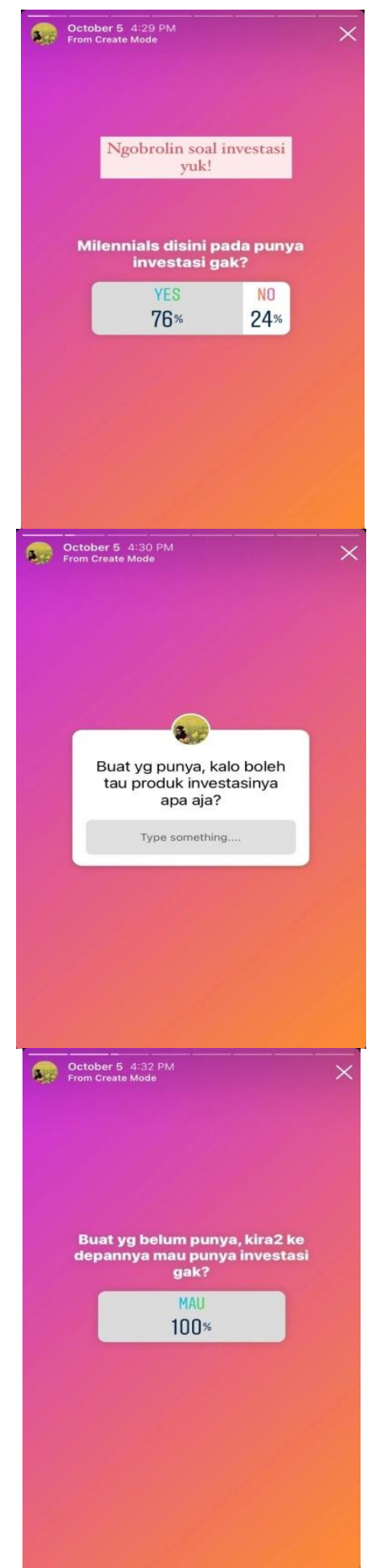

Gambar 2. Proses Pengumpulan Informasi

Perilaku Investasi Generasi Milennial.

Proses pengumpulan informasi dilakukan kembali pada tanggal 7 Desember 2020 untuk mengidentifikasi perilaku 
konsumsi generasi millennial. Proses penggalian informasi tersebut mendapatkan respon yang banyak dari pengguna Instagram yang sangat antusias memberikan informasi mengenai perilaku investasi dan perilaku konsumsi mereka. Setelah didapatkan informasi pengenai kondisi ekonomi, perilaku keuangan, serta permasalahan yang dihadapi oleh generasi millennial, maka kegiatan diskusi dan edukasi literasi keuangan dilaksanakan.

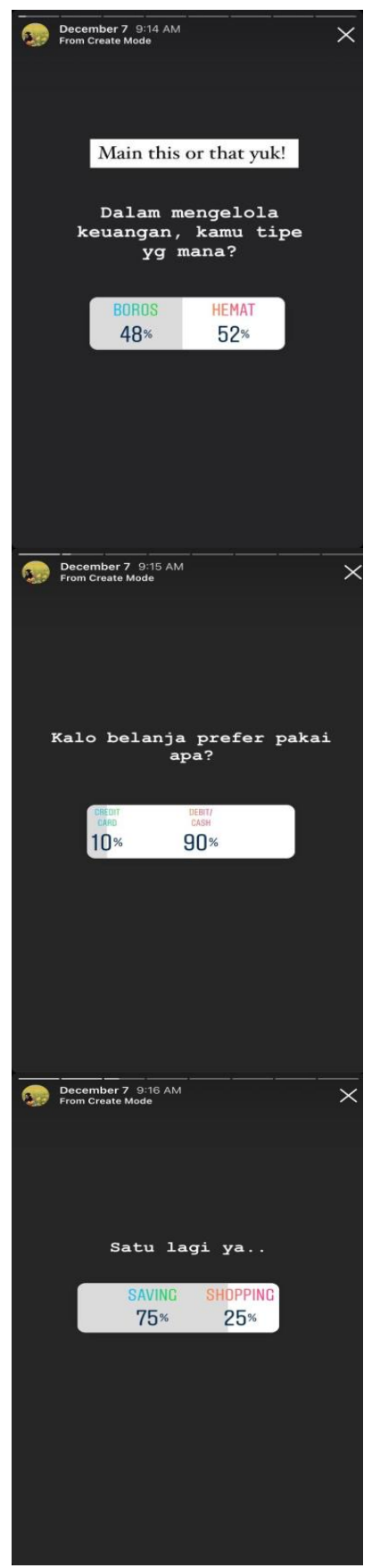

Gambar 3. Proses Pengumpulan Informasi Perilaku Konsumsi di kalangan Milennial.
Sebelum kegiatan tersebut dilakukan, tim melakukan sosialisasi dengan melakukan promosi di media sosial Instagram untuk menjaring peserta. Kegiatan promosi dilakukan dengan memposting poster kegiatan. Informasi yang diberikan meliputi tema, waktu pelaksanaan, nara sumber dan moderator, serta media yang digunakan. Promosi ini dilakukan selama 3 hari berturut-turut sebelum pelaksanaan kegiatan.

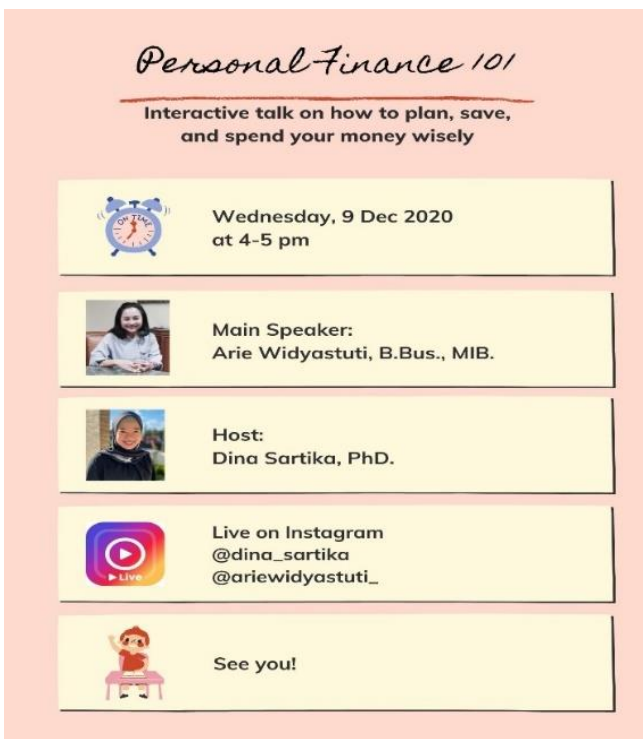

Gambar 4. Poster sosialisasi kegiatan PKM.

Kegiatan edukasi literasi keuangan dilaksanakan pada Hari Rabu, 9 Desember 2020 secara virtual menggunakan fitur Instagram LIVE melalui akun @ dina_sartika dan@ @ ariewidyastuti. Kegiatan ini dilakukan dalam bentuk talk show dengan pembicara Arie Widyastuti, S.E., B.Bus., MIB, dosen manajemen keuangan Fakultas Ekonomi dan Bisnis Universitas Padjadjaran. Acara dipandu oleh Dina Sartika, S.E., M.Si., PhD yang merupakan ketua tim kegiatan PKM ini. Acara berlangsung selama 60 menit secara interaktif. Setelah diskusi selesai, video rekaman kegiatan tersebut diupload di akun Instagram@dina_sartika agar peserta yang tidak dapat menyaksikan diskusi secara langsung tetap dapat menyaksikannya di akun Instagram tersebut. 
Penyuluhan dilaksanakan dalam bentuk diskusi santai dengan mengakomodasi pertanyaan dari para peserta. Bahasa yang digunakanpun sesuai dengan karakter generasi millennial agar pesan yang disampaikan dapat dengan mudah dipahami. Karena latar belakang peserta yang beragam, maka materi yang diberikan pada edukasi literasi keuangan ini berasal dari penelitian empiris maupun buku-buku manajemen keuangan pribadi (personal finance).

Di awal kegiatan peserta diberikan materi mengenai pentingnya perencanaan keuangan, untuk dapat mencapai tujuan keuangan yang ingin dicapai di masa yang yang akan datang. Beberapa tujuan keuangan yang ingin dicapai oleh individu adalah hidup dengan sejahtera, memberikan penghidupan yang baik bagi keluarga, membayar cicilan, dan sebagainya. Perencanaan keuangan dinilai penting karena mayoritas individu merasa lebih mudah untuk menghabiskan uang (spending) disaat sekarang, dibandingkan dengan menabung (saving) di masa yang akan datang (Keown and Hanna, 2003), sehingga dengan adanya perencanaan keuangan yang baik, akan memungkinkan tujuan keuangan tetap tercapai walaupun dimasa krisis (seperti pandemi pada saat ini) atau pada saat kondisi individu tidak memungkinkan untuk produktif (sakit ataupun pensiun).

Diskusi dilanjutkan dengan bagaimana mengevaluasi kesehatan finansial seorang individu. Pada tahap ini peserta dikenalkan dengan pentingnya melakukan pencatatan keuangan, sebagai sumber informasi kesehatan keuangan sekaligus navigasi dalam mencapai tujuan keuangan. Dua jenis laporan keuangan yang penting untuk membuat dan memonitor kondisi keuangan adalah laporan laba rugi/ income statement serta neraca/ balance sheet (Gitman et al., 2013, Keown and Hanna, 2003). Neraca/ balance sheet menggambarkan posisi menganalisis posisi kekayaan yang dimiliki (asset), baik yang bersifat liquid maupun bersifat tetap, beserta sumber pendanaannya (hutang ataukah modal sendiri). Semakin besar asset seseorang didanai oleh hutang, maka kondisi keuangan individu tersebut semakin berisiko. Sementara untuk melihat kinerja pengeloaan keuangan seseorang dapat diperoleh dari income statement yang mencatat besarnya pengeluaran dan pendapatan, sehingga dapat diketahui penghasilan yang diperoleh setiap bulan dapat menutupi biaya yang harus dibayar.

Salah satu alat utama untuk dapat mengelola keuangan dengan baik dengan memiliki literasi keuangan (financial literacy) yang baik. Literasi keuangan diartikan sebagai kemampuan untuk memahami kondisi keuangan serta konsepkonsep keuangan dan untuk merubah pengetahuan itu secara tepat kedalam perilaku (Jacob et al, 2000). Penelitian terdahulu telah menunjukkan bahwa literasi keuangan berkaitan dengan perencanaan yang lebih baik di masa pensiun (Lusardi and Mitchell, 2014), tingkat pendapatan investasi yang lebih tinggi (Clark et al, 2017), kemampuan memperoleh tingkat suku bunga hutang yang lebih rendah (Huston, 2012), dan membantu stabilitas keuangan keluarga, yang dapat membantu terhindar dari konflik dan kekerasan dalam rumah tangga (Ney et al., 1992).

Terlebih seiring dengan perkembangan informasi teknologi dan produk produk keuangan, pemahaman yang baik terkait manfaat, biaya serta pemahaman risiko dan tingkat pengembalian berbagai instrumen keuangan sangat dibutuhkan dalam memilih produk keuangan agar individu dapat terhindar dari transaksi-transaksi yang bersifat financially destructive, dan dapat secara realistis menganalisis berbagai tawaran investasi yang ada. Mengingat mengatur keuangan dengan baik bukan merupakan suatu yang natural dan umum dimiliki (atau bahkan dibahas) oleh individu, maka kemampuan ini harus terus dilatih sejak dini untuk tercapainya penguasaan literasi keuangan yang baik, sehingga pengelolaan keuangan dapat lebih optimal. 
Dalam diskusi juga dibahas mengenai kisaran pembuatan perencanaan keuangan, sebagai monitor agar pendapatan digunakan dengan benar. Mengingat kondisi di masa yang akan datang tidak dapat diprediksi, maka risiko yang timbul dari ketidakpastian akan selalu ada. Oleh karena itu, walaupun investasi jangka panjang sangat diperlukan, kepemilikan dana darurat juga harus dipertimbangkan sebagai antisipasi hal-hal yang tidak diinginkan. Perhitungan alokasi anggaran keuangan pada pelatihan ini mengacu pada konsep CEPIL yang dikemukakan oleh Karvof (2013), yang meliputi:

1. Charity (amal) sebesar $10 \%$ dari total penghasilan

2. Education and Protection (pendidikan dan asuransi) sebesar $20 \%$ dari total penghasilan

3. Investasi sebesar $30 \%$ dari total penghasilan

4. Live cost (biaya hidup) sebesar $40 \%$ dari total penghasilan.

Kegiatan ini juga membahas topik berbagai alternatif investasi secara umum, yang dapat menambah nilai dari waktu ke waktu, sehingga kesejahteraan pada jangka panjang dapat tercapai. Alternative investasi yang dibahas dalam diskusi ini meliputi investasi surat berharga, seperti saham dan obligasi, emas, maupun rumah. Sebagai penutup diskusi membahas risiko dan manfaat pengunaan kartu kredit, sehingga peserta dapat memanfaatkannya secara bijak.

Sampai dengan Bulan Januari 2021, video tersebut telah disaksikan oleh lebih dari 600 orang. Angka tersebut dapat terus bertambah selama video tersebut masih terposting di media sosial. Jika semakin banyak generasi millennial dan masyarakat yang menyaksikan video tersebut, maka akan semakin tinggi juga pemahaman masyarakat Indonesia tentang manajemen keuangan. Diharapkan, tingkat literasi keuangan di kalangan generasi millennial Indonesia akan meningkat.

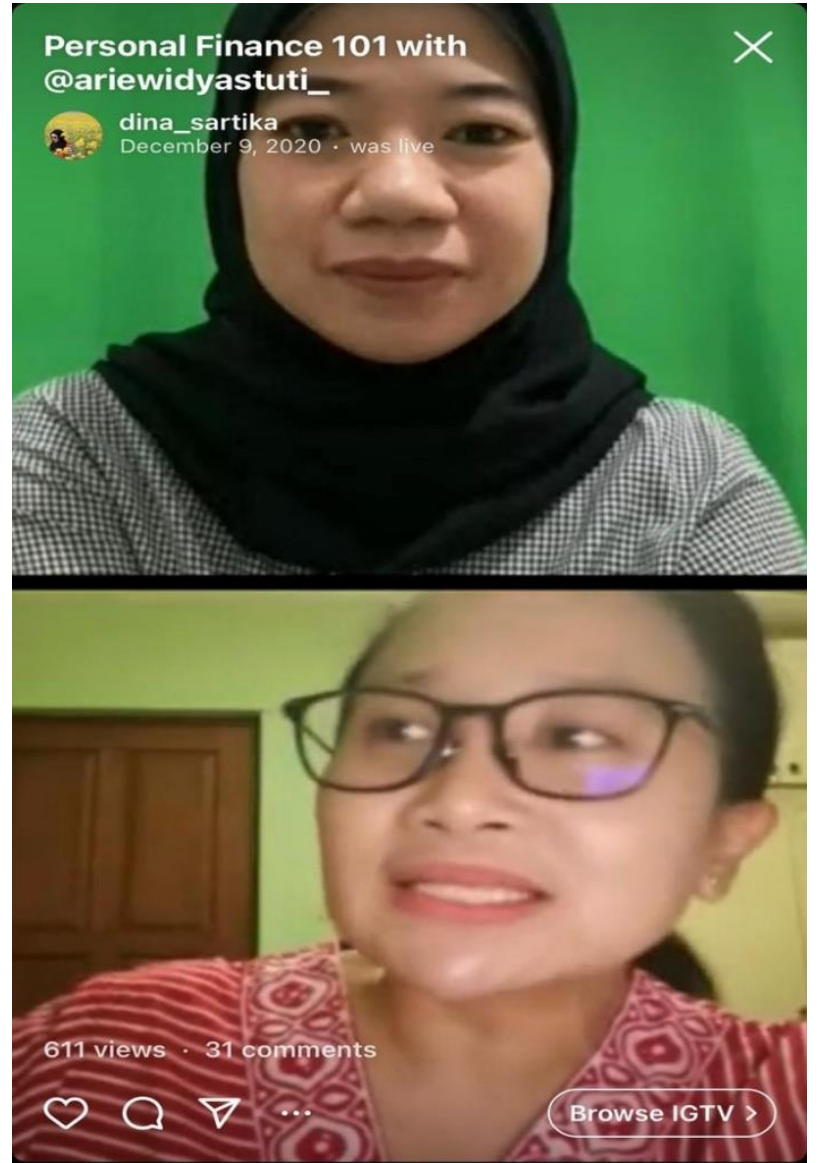

Gambar 5. Video Kegiatan Sosialisasi Literasi Keuangan.

Berdasarkan kegiatan yang dilakukan, maka pengukuran keberhasilan dari sosialisasi dan edukasi literasi dan pengelolaan keuangan secara rinci dapat dilihat pada Tabel 1 .

Tabel. 1. Hasil dan Luaran Kegiatan PKM

\begin{tabular}{|l|l|l|l|}
\hline No & Indikator & $\begin{array}{l}\text { Base Line } \\
\text { (sebelum } \\
\text { kegiatan) }\end{array}$ & $\begin{array}{c}\text { Luaran } \\
\text { (Setelah } \\
\text { Kegiatan) }\end{array}$ \\
\hline 1 & $\begin{array}{l}\text { Peserta } \\
\text { memahami } \\
\text { pengetahuan } \\
\text { mendasar } \\
\text { seputar } \\
\text { literasi } \\
\text { keuangan }\end{array}$ & $\begin{array}{l}\text { Peserta } \\
\text { belum } \\
\text { mengetah } \\
\text { ui } \\
\text { beberapa } \\
\text { konsep } \\
\text { dasar } \\
\text { literasi } \\
\text { keuangan } \\
\text { secara } \\
\text { memaham } \\
\text { i dan lebih } \\
\text { menyadari } \\
\text { pentingny } \\
\text { a memiliki } \\
\text { literasi } \\
\text { keuangan }\end{array}$ \\
\hline 2 & $\begin{array}{l}\text { Peserta } \\
\text { memahami }\end{array}$ & $\begin{array}{l}\text { Peserta } \\
\text { belum }\end{array}$ & $\begin{array}{l}\text { Peserta } \\
\text { memaham }\end{array}$ \\
\hline
\end{tabular}




\begin{tabular}{|c|c|c|c|}
\hline & $\begin{array}{l}\text { arti } \\
\text { pentingnya } \\
\text { pengelolaan } \\
\text { keuangan } \\
\text { dan } \\
\text { memahami } \\
\text { tujuan } \\
\text { pengelolaan } \\
\text { keuangan }\end{array}$ & $\begin{array}{l}\text { memaha } \\
\text { mi arti } \\
\text { dan } \\
\text { tujuan } \\
\text { pengelola } \\
\text { an } \\
\text { keuangan }\end{array}$ & $\begin{array}{l}\text { i arti dan } \\
\text { tujuan } \\
\text { pengelolaa } \\
\mathrm{n} \\
\text { keuangan }\end{array}$ \\
\hline 3 & $\begin{array}{l}\text { Peserta } \\
\text { memahami } \\
\text { dan mampu } \\
\text { melakukan } \\
\text { pengelolaan } \\
\text { keuangan }\end{array}$ & $\begin{array}{l}\text { Peserta } \\
\text { belum } \\
\text { mampu } \\
\text { melakuka } \\
\mathrm{n} \\
\text { pengelola } \\
\text { an } \\
\text { keuangan } \\
\text { dengan } \\
\text { baik }\end{array}$ & $\begin{array}{l}\text { Peserta } \\
\text { mampu } \\
\text { melakukan } \\
\text { pengelolaa } \\
\mathrm{n} \\
\text { keuangan } \\
\text { dengan } \\
\text { baik }\end{array}$ \\
\hline 4 & $\begin{array}{l}\text { Peserta } \\
\text { mengerti tipe } \\
\text { - tipe } \\
\text { tabungan } \\
\text { dan } \\
\text { instrumeninv } \\
\text { estasi yang } \\
\text { ditawarkan } \\
\text { oleh } \\
\text { berbagai } \\
\text { Lembaga } \\
\text { Keuangan } \\
\text { dan dapat } \\
\text { memahami } \\
\text { risiko } \\
\text { keuangan } \\
\text { yang } \\
\text { melekat pada } \\
\text { instrumen } \\
\text { keuangan } \\
\text { tersebut }\end{array}$ & $\begin{array}{l}\text { Peserta } \\
\text { belum } \\
\text { paham } \\
\text { terhadap } \\
\text { konsep } \\
\text { risiko } \\
\text { dalam } \\
\text { investasi }\end{array}$ & $\begin{array}{l}\text { Peserta } \\
\text { mengetahu } \\
\text { i dan } \\
\text { mamaham } \\
\text { i konsep } \\
\text { risiko } \\
\text { dalam } \\
\text { investasi }\end{array}$ \\
\hline 5 & $\begin{array}{l}\text { Peserta } \\
\text { mampu } \\
\text { memilih tipe } \\
\text { tabungan } \\
\text { dan investasi } \\
\text { yang sesuai } \\
\text { untuk } \\
\text { merencanaka } \\
\text { n masa }\end{array}$ & $\begin{array}{l}\text { Peserta } \\
\text { belum } \\
\text { mampu } \\
\text { memilih } \\
\text { tipe } \\
\text { tabungan } \\
\text { dan } \\
\text { investasi } \\
\text { yang } \\
\text { sesuai }\end{array}$ & $\begin{array}{l}\text { Peserta } \\
\text { mampu } \\
\text { memilih } \\
\text { tipe } \\
\text { tabungan } \\
\text { dan } \\
\text { investasi } \\
\text { yang } \\
\text { sesuai } \\
\text { untuk } \\
\end{array}$ \\
\hline
\end{tabular}

\begin{tabular}{|l|l|l|l|}
\hline depan & untuk & merencana \\
mereka & merencan & kan masa \\
akan & depan \\
& masa & mereka \\
& depan & \\
& mereka & \\
\hline
\end{tabular}

\section{KESIMPULAN DAN SARAN}

Kemampuan mengelola keuangan pribadi merupakan kompetensi yang harus dimiliki oleh setiap individu karena akan berdampak pada perilaku dan pengambilan keputusan sehari-hari. Sebaliknya, pengelolaan keuangan yang buruk akan berdampak pada perilaku masyarakat yang rentan akan krisis keuangan dan berpotensi mengalami kerugian akibat kejahatan di sektor keuangan. Tingkat literasi keuangan dipengaruhi oleh faktor demografis dan Generasi Millennial memiliki literasi keuangan terrendah dibanding generasi lainnya.

Edukasi mengenai literasi keuangan perlu terus dilakukan dalam upaya meningkatkan kemampuan masyarakat khususnya generasi millennial dalam pengambilan keputusan keuangan. Jika hal tersebut dilakukan secara konsisten, maka dapat membantu millennial dalam mengatur gaya hidup dan perilaku keuangan yang semakin baik dan benar. Agar dapat terwujud program yang berkelanjutan, kegiatan ini sebaiknya dilakukan secara kontinyu. Tentu saja banyak sekali permasalahan sosial yang dihadapi oleh generasi millennial Indonesia saat ini. Untuk itu, kegiatan PKM selanjutnya dapat dilakukan dengan mengusung topik lanjutan dari literasi keuangan, atau mengangkat topik yang berbeda untuk menyelesaikan masalah generasi millennial lainnya.

\section{DAFTAR PUSTAKA}

Terimakasih yang sebesar-besarnya kami ucapkan kepada Universitas Padjadjaran khususnya Direktorat Riset dan Pengabdian Kepada Masyarakat yang telah 
memberikan dukungan finansial untuk kegiatan ini melalui Hibah Internal Unpad (Unpad Research Grant) tahun 2020.

\section{DAFTAR PUSTAKA}

Azizah, N. S. (2020). Pengaruh literasi keuangan, gaya hidup pada perilaku keuangan pada generasi milenial. Prisma (Platform Riset Mahasiswa Akuntansi), 01(02), 92-101.

Chen, H., \& Volpe, R. . (1998). An analysis of Personal Financial Literacy Among College Students. Financial Services Review, 7(2), 107-128.

Clark, R., Lusardi, A. \& Mitchell, O. S. (2017). Financial Knowledge And 401 (K) Investment Performance: A Case Study. Journal Of Pension Economics \& Finance, 16, 324-347.

Gitman, L., Joehnk, M. \& Billingsley, R. (2013). Personal Financial Planning, Nelson Education.

Hussain, I., \& Sajjad, S. (2016). Significance of Financial Literacy and It's Implications: A Discussion. Journal of Business Strategies, 10(2), 141-154.

Huston, S. J. (2012). Financial Literacy And The Cost Of Borrowing. International Journal Of Consumer Studies, 36, 566572.

Jacob, K., Hudson, S. \& Bush, M. (2000). Tools For Survival: An Analysis Of Financial Literacy Programs. Woodstock Institute, Jan.

Karvof, A. (2013). Kaya Dengan Cepil, Elex Media Komputindo.

Keown, A. J. \& Hanna, S. D. (2003). Personal Finance: Turning Money Into Wealth.

Lusardi, A. \& Mitchell, O. S. (2014). The Economic Importance Of Financial Literacy: Theory And Evidence. Journal Of Economic Literature, 52, 544.

Ney, P. G., Fung, T. \& Wickett, A. R. (1992). Causes Of Child Abuse And Neglect. The Canadian Journal Of Psychiatry, 37, 401-405.

Ningtyas, M. N. (2019). Literasi Keuangan pada Generasi Milenial. Jurnal Ilmiah Bisnis Dan Ekonomi Asia, 13(1), 2027.

https://doi.org/10.32812/jibeka.v13i1.1 11

Prayustika, A. P., Suryadi, I. G. I., Arsawan, E. W. I., \& Widiantara, M. I. (2020). Peran Financial Technology Dalam Meningkatkan Literasi Keuangan Mahasiswa. Seminar Nasional Terapan Riset Inovatif (SENTRINOV) Ke-6, 6(2), 262-267. https://doi.org/10.4324/978042934401 5-2

Rosdiana, R. (2020). Investment Behavior in Generation $\mathrm{Z}$ and Millennial Generation. Dinasti International Journal of Economics, Finance \& Accounting, 1(5), 766-780. https://doi.org/10.38035/DIJEFA

Yolanda, Y., \& Tasman, A. (2020). Pengaruh Financial Literacy dan Risk Perception terhadap Keputusan Investasi Generasi Millennial Kota Padang. Jurnal Ecogen, 3(1), 144. https://doi.org/10.24036/jmpe.v3i1.853 3. 